\title{
PALAVRAS DO PROF. DR. DOMINGO M. BRAILE
}

Prezados colegas,

Em primeiro lugar, quero agradecerIhes a confiança ao eleger-me para o mandato de seis anos como Editor da Revista Brasileira de Cirurgia Cardiovascular (RBCCV). A responsabilidade de substituir os Editores que me precederam, detentores de qualidades inigualáveis, pesa sobre meus ombros, mas espero, pelo menos, poder continuar o trabalho sério com o qual conduziram a RBCCV desde o seu nascedouro até os dias atuais.

Prometo trabalhar com afinco no sentido de tornar a nossa Revista, que já é de excelente qualidade, em uma publicação ainda melhor e mais ágil por meio da incorporação dos recursos de informática agora disponíveis. As nossas outras grandes metas serão: aumentar a circulação da publicação, como já era idéia dos Editores que me precederam, e ter uma versão eletrônica da mesma em inglês para possibilitar a nossa presença científica em todo o mundo.

Para isto contamos com o auxílio da Scielo, que pode ser acessada no endereço: (http://www.scielo.br), onde a Revista da SBCCV tem as edições desde 1997 (inclusive) com "abstracts" e textos completos em português no site: http://www.scielo.br/ scielo.php?script=sci_serial\&pid=0102$7638 \&$ Ing=en\&nrm=iso . Temos a promessa de que até o final deste ano será possível colocar ali também os artigos em inglês, que poderão ser consultados diretamente através da nossa página presente na CTSNET (http://www.ctsnet.org), localizada nos Estados Unidos, cujo endereço é: http:// www.sbccv.org .

Para que estes objetivos sejam alcançados, a publicação terá de sofrer uma série de mudanças. A primeira delas estará implementada já na edição 17.2, cuja capa terá um visual mais limpo e agradável. Em breve, novas sessões deverão ser criadas na Revista, visando aspectos técnicos, burocráticos e éticos, além de cartas ao Editor, apresentação de casos, bolsa de empregos, oportunidades e outros.

A versão eletrônica em inglês certamente nos colocará em pé de igualdade com as revistas internacionais da área médica e permitirá que os artigos dos cirurgiões cardíacos brasileiros sejam apreciados e citados em todo o planeta, abrindo a possibilidade para que sejamos aceitos no MEDLINE e no ISI - fundamentais para mantermos o "QUALIS A" de que somos detentores pelo esforço do Prof. Dr. Fabio Jatene e seus colaboradores.

A RBCCV caminha a passos largos para a sua informatização completa, sendo indispensável a colaboração de todos para que os objetivos sejam atingidos. Desta forma os manuscritos deverão ser encaminhados eletronicamente em DISQUETE ou CDROM para:

Revista Brasileira de Cirurgia Cardiovascular

AV Juscelino Kubitschek de Oliveira, 1505 CEP 15091-450

São José do Rio Preto SP Brasil 
Ou ainda poderão ser enviados pela INTERNET para o endereço eletrônico:

revista@sbccv.com.br

Não se esquecendo de colocar no campo assunto (subject) o nome do artigo. Os textos devem ser editados em Word e gráficos, fotos, tabelas etc, cada um deles em um arquivo em separado.

Tais procedimentos já são normais em muitas publicações, facilitando e agilizando o fluxo de informações. A revisão dos manuscritos pelos Editores Associados e pelos "pares" do Conselho Editorial também será realizada por processo eletrônico, com utilização de questionários padronizados enviados e recebidos pela INTERNET para apreciação final do Editor. Brevemente os autores poderão ter acesso ao andamento da avaliação dos seus manuscritos e receberão as sugestões para eventuais correções ou adequações também via E-MAIL.
Somente será possível avaliar esse salto de qualidade com o envolvimento de todos, que certamente desejam que a RBCCV seja o espelho a refletir a seriedade e o alto nível científico que a Cirurgia Cardiovascular atingiu no Brasil e que merece ser conhecida pelos colegas de todos os continentes. Esperamos receber um grande número de excelentes manuscritos, que contribuam para o engrandecimento da nossa Sociedade e da nossa Revista. Críticas e sugestões serão sempre bem-vindas e examinadas com o respeito que merecem. Fiquem certos de que estaremos sempre abertos ao diálogo e à disposição de todos.

Recebam meus agradecimentos e um caloroso abraço,
Domingo M. Braile Editor - RBCCV 